\title{
Nematode Management in Potatoes (Irish or White) ${ }^{1}$
}

\author{
Zane J. Grabau and J. W. Noling 2
}

Plant-parasitic nematodes are small, microscopic roundworms that feed on plant tissue. Most plant-parasitic nematodes live in the soil and attack the roots of plants. Crop production problems induced by nematodes therefore generally occur as a result of root dysfunction; nematodes reduce rooting volume and the efficiency with which roots forage for and use water and nutrients. This reduced root function leads to reduced crop yields. Many different genera and species of nematodes cause damage in Florida potato production. In many cases, a mixed community of plant-parasitic nematodes is present in a field, rather than a single species alone. The most important nematode pests of potatoes (Solanum tuberosum L.) in Florida are species of root-knot (principally Meloidogyne incognita), sting (Belonolaimus longicaudatus; https://edis.ifas.ufl.edu/ in395), and stubby-root nematodes (primarily Nanidorus minor; https://edis.ifas.ufl.edu/in616). Stubby-root nematodes are important primarily because they vector tobacco rattle virus, which causes corky ringspot disease (CRS) in the Hastings region of northeast Florida (Perez et al. 2000). Common CRS symptoms are internal and external rings of necrosis (Figures 3 and 4). Several other nematodes, including spiral (Helicotylenchus spp.), lesion (Pratylenchus spp.), awl (Dolichodorus spp.), stunt (Tylenchorhynchus spp.), and sheath (Hemicycliophora spp.), are occasionally associated with reduced yields or quality of potatoes in Florida.

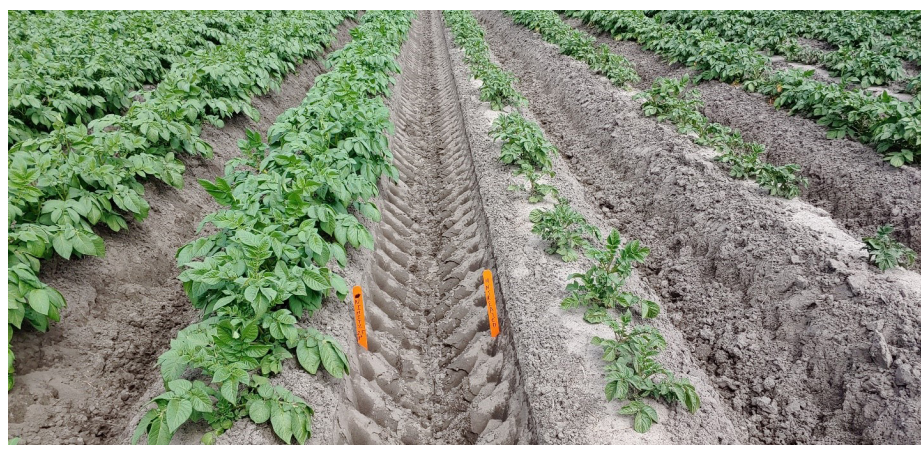

Figure 1. Stunting of potato shoots due to sting nematode infestation. Stunted plants on the right are not treated with any nematicide. More vigorous plants on the left are treated with Nimitz nematicide. Photo is from 41 days after planting. Credits: Zane Grabau, UF/IFAS

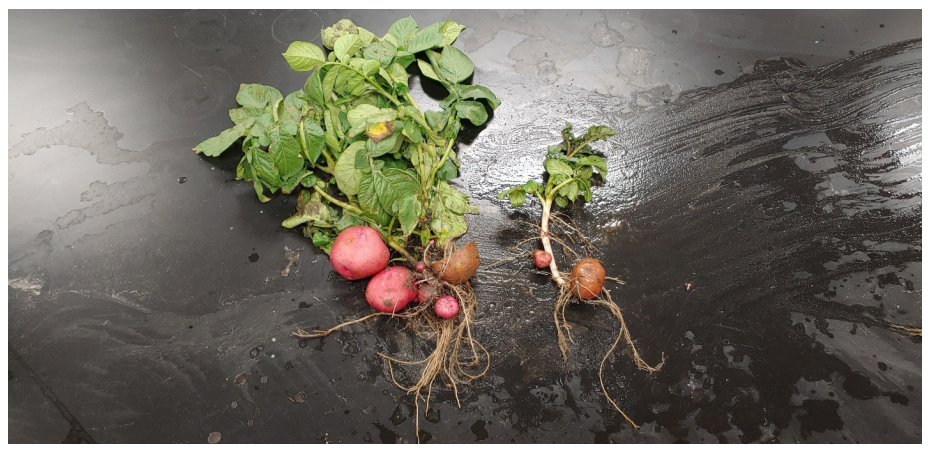

Figure 2. Potato root and shoot systems stunted by sting nematode infestation. The plant on the left was treated with nematicide whereas the plant on the right was not treated.

Credits: Zane Grabau, UF/IFAS

1. This document is ENY-029, one of a series of the Entomology and Nematology Department, UF/IFAS Extension. Original publication date February 2002. Revised December 2009, December 2012, December 2016, and August 2019. Visit the EDIS website at http://edis.ifas.ufl.edu. J. W. Noling, professor, Entomology and Nematology Department; UF/IFAS Citrus Research and Education Center, Lake Alfred, FL 33850 wrote earlier versions of this publication.

2. Zane J. Grabau, assistant professor, field crop nematology, Entomology and Nematology Department; and J. W. Noling, professor, Entomology and Nematology Department; UF/IFAS Citrus Research and Education Center; UF/IFAS Extension, Gainesville FL 32611.

The Institute of Food and Agricultural Sciences (IFAS) is an Equal Opportunity Institution authorized to provide research, educational information and other services

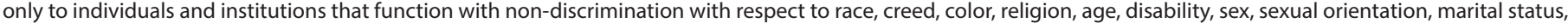
national origin, political opinions or affiliations. For more information on obtaining other UF/IFAS Extension publications, contact your county's UF/IFAS Extension office. U.S. Department of Agriculture, UF/IFAS Extension Service, University of Florida, IFAS, Florida A \& M University Cooperative Extension Program, and Boards of County Commissioners Cooperating. Nick T. Place, dean for UF/IFAS Extension. 


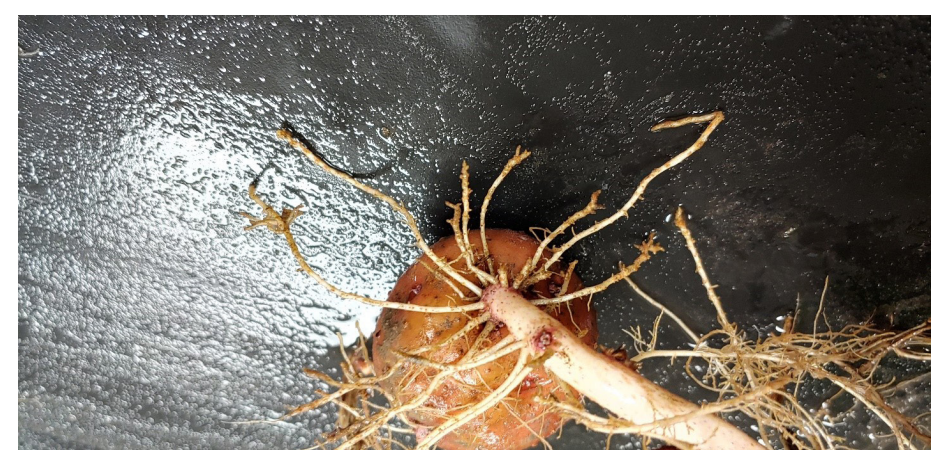

Figure 3. Potato roots affected by sting nematode infestation. Lateral roots are severely stunted, root tips are slightly swollen and necrotic (browning), and lateral roots have proliferated into small mats in portions of the root system.

Credits: Zane Grabau, UF/IFAS

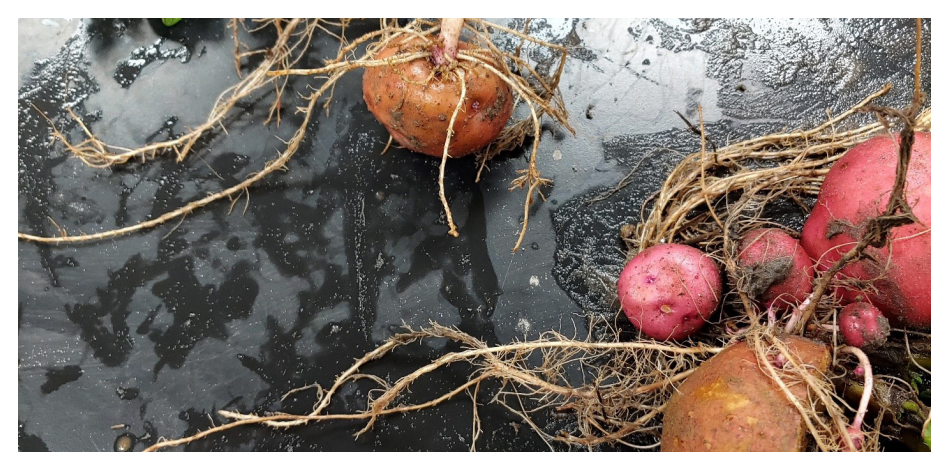

Figure 4. The collection of soil samples for nematode analysis can be acquired from the field using cylindrical sampling tubes, a trowel, a bucket auger, or a shovel.

Credits: Zane Grabau, UF/IFAS

\section{General IPM Considerations}

Integrated pest management (IPM) for nematodes requires:

- Determining whether pathogenic nematodes are present within the field;

- Determining whether nematode population densities are high enough to cause economic loss; and

- Selecting a profitable management option.

Attempts to manage nematodes may be unprofitable unless all of the above IPM procedures are considered and carefully followed. Similarly, some management methods pose risk to people and the environment. Therefore, it is important to know that their use is justified by actual conditions in a field and that certified applicators are overseeing their use.

Nematode species and population levels, incidence of soilborne diseases and insects, soil moisture at field preparation time, and the intended market for the potatoes can all affect the choice of nematode control measures. Growers should use a combination of many different kinds of control measures when feasible, because no single measure provides perfect protection for the crop. Growers should also be aware that the host range of these nematodes includes many different weeds and most if not all of the commercially grown vegetables within the state. Yield reductions can be extensive but vary significantly between plant and nematode species. In addition to the direct crop damage caused by nematodes, many of these species have also been shown to predispose plants to infection by fungal or bacterial pathogens or to transmit virus diseases, which contribute to additional yield reductions.

\section{Biology and Life History}

Most species of plant-parasitic nematodes have a relatively simple life cycle consisting of the egg, four juvenile stages, and the adult male and female. Development of the first-stage juvenile occurs within the egg, where the first molt occurs. Second-stage juveniles hatch from eggs to find and infect plant roots. Host finding or movement in soil occurs within surface films of water surrounding soil particles and root surfaces. Depending on the species, feeding will occur along the root surface; in some species like root-knot, young larval stages will invade root tissue, establishing permanent feeding sites within the root. Second-stage larvae will then molt three times to become adult males or females. For most species of nematodes, as many as 50 to 100 eggs are produced per female. In others, such as root-knot, upwards of 2000 eggs may be produced (Figure 2). Under suitable environmental conditions, the eggs hatch, and new larvae emerge to complete the life cycle within 4 to 8 weeks depending on temperature. Nematode development is generally most rapid within an optimal soil temperature range of $70^{\circ} \mathrm{F}$ to $80^{\circ} \mathrm{F}$ in the plant root zone.

\section{Symptoms}

Typical symptoms of nematode injury can involve both aboveground and belowground plant parts. Foliar symptoms of nematode infestation of roots generally involve stunting and general unthriftiness, premature wilting and slow recovery to improved soil moisture conditions, leaf chlorosis (yellowing), and other symptoms characteristic of nutrient deficiency (Figure 1). An increased rate of ethylene production, thought to be largely responsible for symptom expression in tomato, has been shown to be closely associated with root-knot nematode root infection and gall formation. Plants exhibiting stunt or decline symptoms usually occur in patches of nonuniform growth rather than as an overall decline of plants within an entire field.

The time in which symptoms of plant injury occur is related to nematode population density, crop susceptibility, and prevailing environmental conditions. For example, under 
heavy nematode infestation, crop seedlings may fail to develop, maintaining a stunted condition, or die, causing poor or patchy stand development. Under less severe infestation levels, symptom expression may be delayed until later in the crop season after a number of nematode reproductive cycles have been completed on the crop. In this case, aboveground symptoms will not always be readily apparent early within crop development, but with time and reduction in root system size and function, symptoms will become more pronounced and diagnostic.

Root symptoms induced by sting or root-knot nematodes are often more specific than aboveground symptoms. Sting nematode can be very injurious, causing infected plants to form a tight mat of short roots, often swollen at the tips (Figures 2, 3, and 4). New root initials generally are killed by heavy infestations of the sting nematode, resembling fertilizer salt burn. Additionally, high populations of sting nematodes are often associated with severely misshapen, scruffy, and abnormally russetted tubers (Figure 5). Root symptoms induced by root-knot nematodes are swollen areas (galls) on the roots of infected plants (Figure 6). Gall size may range from a few spherical swellings to extensive areas of elongated, convoluted, tumorous swellings which result from exposure to multiple and repeated infections. Similarly, root-knot nematode induces galling on tubers, which results in a warty or bumpy appearance (Figure 7). Symptoms of root or tuber galling can in most cases provide positive diagnostic confirmation of root-knot nematode presence, infection severity, and potential for crop damage. Common symptoms of CRS, which is vectored by stubby-root nematodes, are internal and external rings of necrosis (Figures 8 and 9).

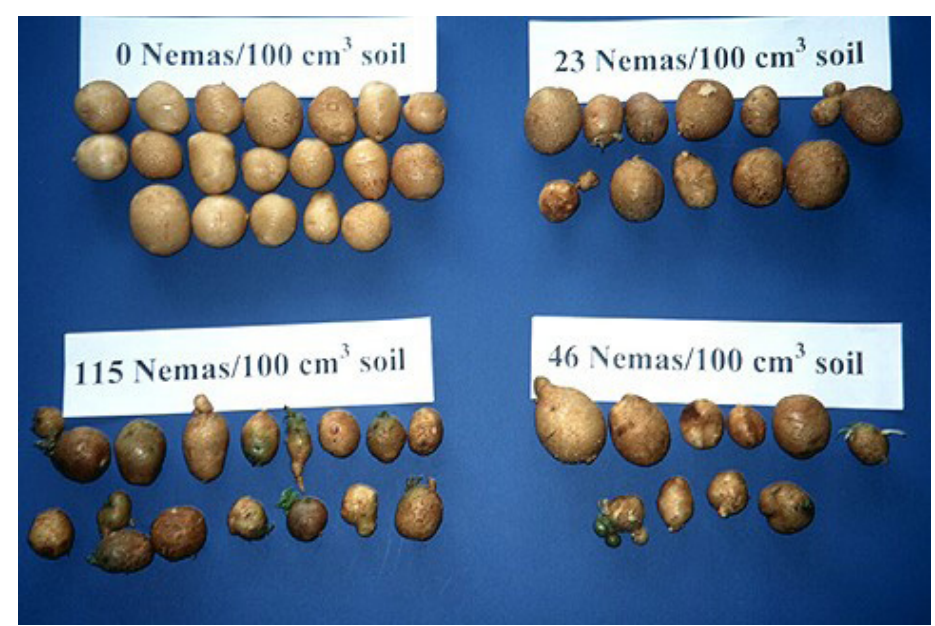

Figure 5. Potato tuber damage by sting nematode. The incidence of small, misshapen, green, and otherwise damaged tubers increases as the initial population of sting nematodes increases.

Credits: William Crow, UF/IFAS

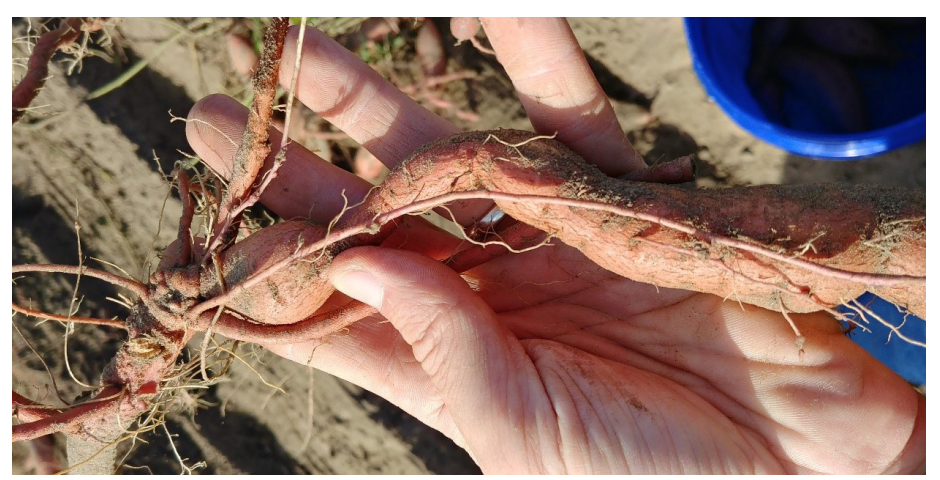

Figure 6. The small, knotty swellings on the roots of this sweet potato are galls caused by root-knot nematode infection.

Credits: Zane Grabau, UF/IFAS

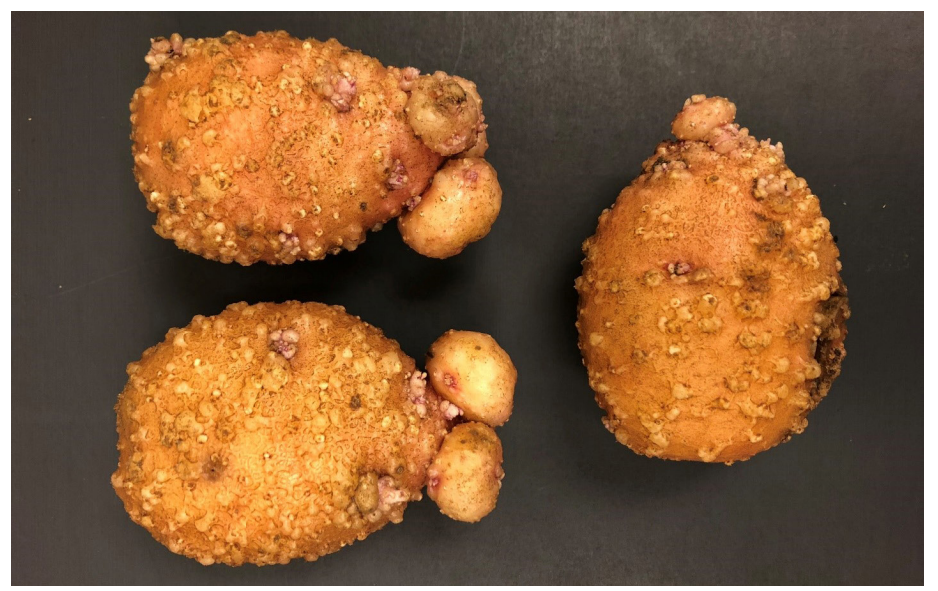

Figure 7. Galls on potato induced by root-knot nematode (Meloidogyne spp.) giving a warty tuber surface appearance. Credits: Abolfazl Hajihassani, University of Georgia (used with permission)

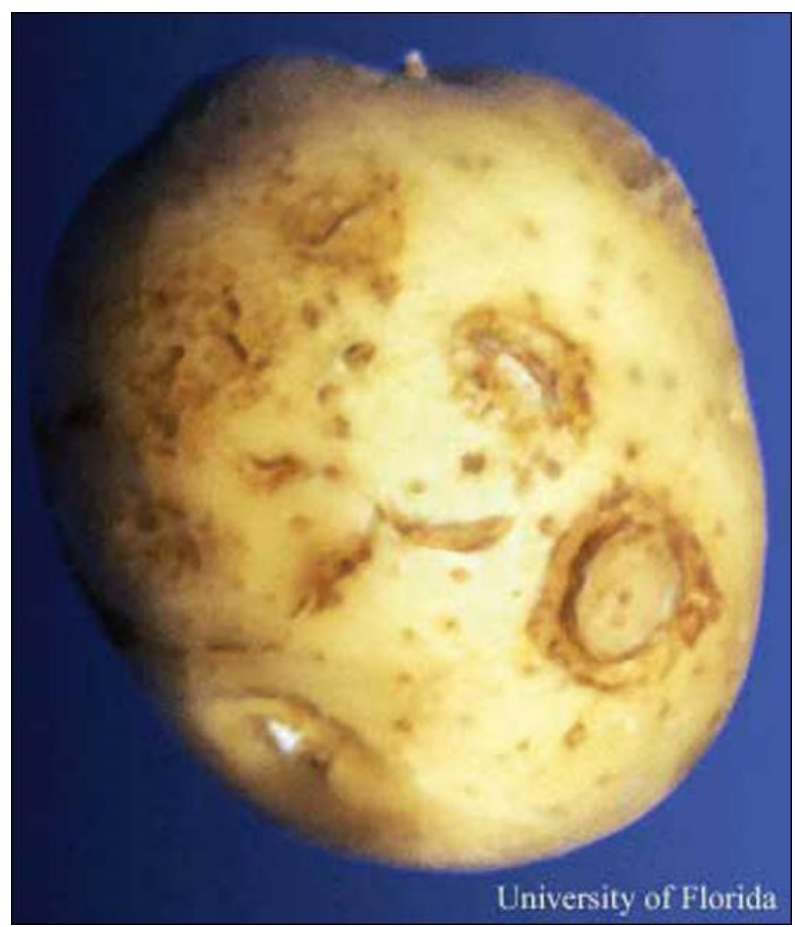

Figure 8. Potato tuber with external brown rings, a symptom of corky ringspot disease transmitted by stubby-root nematode.

Credits: D. P. Weingartner, University of Florida 


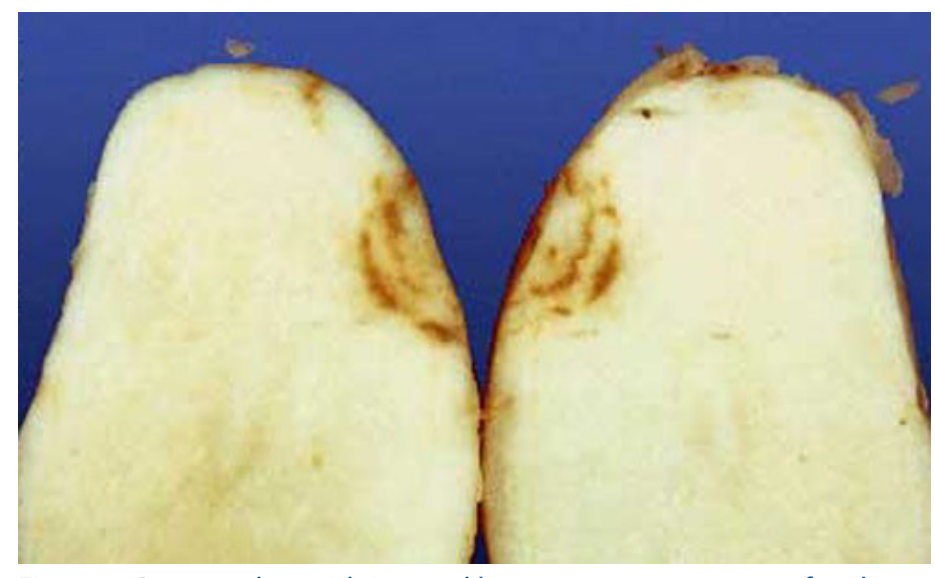

Figure 9. Potato tuber with internal brown arcs, a symptom of corky ringspot disease transmitted by stubby-root nematode.

Credits: D. P. Weingartner, University of Florida

\section{Damage}

Plant-parasitic nematodes may reduce potato yield by impairing root function leading to reduced growth or causing cosmetic damage to tubers reducing or eliminating market value. Sting and root-knot nematodes cause potato yield reductions by impairing plant growth and deforming tubers. Stubby-root nematodes apparently cause little direct damage to potatoes, but the corky ringspot disease they vector causes serious tuber quality defects.

For most crop and nematode combinations, the damage caused by nematodes has not been accurately determined. Most vegetable crops produced in Florida are susceptible to nematode injury, particularly by root-knot and sting nematodes. Plant symptoms and yield reductions are often directly related to preplant infestation levels in soil and to other environmental stresses imposed upon the plant during crop growth. As infestation levels increase, so does the amount of damage and yield loss. The mere presence of sting, root-knot, or stubby-root nematodes generally warrants management. Work in the northeast Florida region of potato production established that the economic threshold (nematode population at which management will bring an economic return) was 2 to 3 sting nematodes/ 130 $\mathrm{cm}^{3}$ soil based on prices in 2000 (Crow et al. 2000). Because the surface and internal defects caused or vectored by root-knot and stubby-root nematodes render infected potatoes unmarketable, low populations of these nematodes can cause sizeable loss in marketable yield. Additionally, root-knot nematodes exacerbate bacterial wilt damage from Pseudomonas solanacearum (Weingartner and Shumaker 1990a).

\section{Field Diagnosis and Sampling}

Due to nematodes' microscopic size and irregular field distribution, soil and root tissue samples are usually required to determine if nematodes are causing poor crop growth and whether nematode management is needed. For nematodes, sampling and management are a preplant or postharvest consideration. If a problem develops in a newly planted crop, there are currently no post-plant corrective measures available. Therefore, nematode population density and distribution within a field must be accurately determined before planting by collecting and submitting a representative sample from the field.

\section{Advisory or Predictive Sample (Prior to Planting)}

Samples taken to predict the risk of nematode injury to a newly planted crop must be collected well in advance of planting to allow for sample analysis and treatment periods if required. For best results, sample for nematodes at the end of the growing season, before crop destruction, when nematodes are most numerous and easiest to detect. Collect soil and root samples from 10 to 20 field locations using a cylindrical sampling tube, a trowel, or a shovel. Since most species of nematodes are concentrated in the crop rooting zone, samples should be collected to a soil depth of at least 6 to 10 inches. Sample in a regular pattern over the area, emphasizing removal of samples across rather than along rows (Figure 10). For potatoes, one sample should be collected from no more than 5 acres. Fields with different crops (or varieties) during the past season, or with obvious differences either in soil type or previous history of cropping problems, should be sampled separately. Sample only when soil moisture is appropriate for working the field. Avoid extremely dry or wet soil conditions.

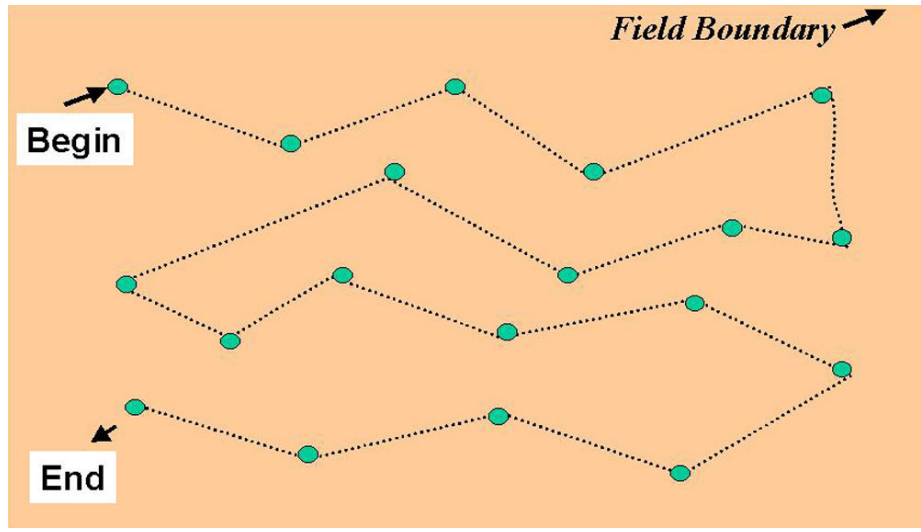

Figure 10. Suggested pattern for collecting preplant soil samples for nematode analysis based on compositing soil from 10 to 20 field locations.

Credits: Joe Noling, UF/IFAS 


\section{Diagnostics on Established Plants}

Roots and soil cores should be removed to a depth of 6 to 10 inches from 10 to 20 suspect plants. Avoid dead or dying plants, since their roots will often harbor few nematodes.

For seedlings or young transplants, excavation of individual plants may be required to ensure sufficient quantities of infested roots and soil. Submission of additional samples from adjacent areas of good growth should also be considered for comparative purposes (Figure 11).

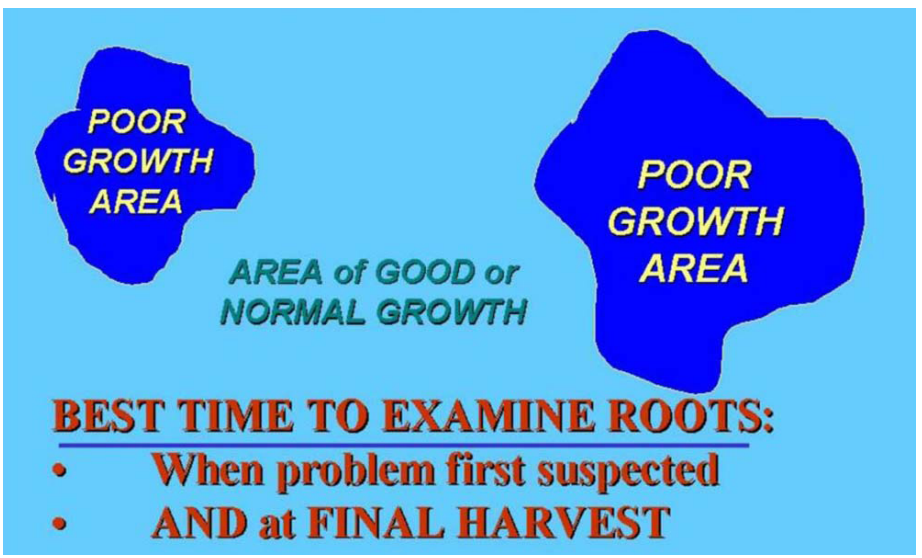

Figure 11. Suggested strategy for collecting post-plant soil samples for nematode analysis comparing sampling results from areas of good and poor plant growth.

Credits: Joe Noling, UF/IFAS

For either type of sample, once all soil cores or samples are collected, the entire sample should be mixed thoroughly but carefully, and a 1- to 2-pint subsample placed into an appropriately labeled plastic bag. Remember to include sufficient feeder roots. The plastic bag will prevent drying of the sample and guarantee an intact sample upon arrival at the laboratory. Never subject the sample(s) to overheating, freezing, drying, or to prolonged periods of direct sunlight. Samples should always be submitted immediately to the UF/IFAS Nematode Assay Laboratory or a reputable commercial laboratory for analysis. If sample submission is delayed, then temporary refrigerated storage at temperatures of $40^{\circ} \mathrm{F}$ to $60^{\circ} \mathrm{F}$ is recommended. Nematodes are typically identified and quantified to genera level (i.e., root-knot nematode vs. sting nematode) unless otherwise requested. In potato production, nematode identification to genera level is typically sufficient to gauge risk of damage from nematodes and inform selection of chemical management options. If considering particular crop rotations for nematode management, identification of any root-knot nematodes present in the field to species level (cotton rootknot nematode vs. peanut root-knot nematode) may be necessary to select a proper crop or cultivar. Species-level identification can be done in the UF/IFAS Nematode Assay Laboratory upon request.
If root-knot nematodes are the primary nematode problem in a field, direct assessment of incidence and severity of root or tuber galling by an agricultural professional proficient at recognizing these symptoms can be useful for determining relative nematode pressure and incidence. Contact your local UF/IFAS Extension agent or Z. J. Grabau for assistance with this assessment. Root gall severity is a simple measure of the proportion of the root system that is galled. In general, soil population levels increase with root gall severity. Around harvest, but before potatoes are removed from the field, a sufficient number of plants should be carefully removed from soil and examined to characterize the nature and extent of the problem within the field. Alternatively, samples of tubers from different regions of the field can be saved for examination. In many cases, this form of sampling can provide immediate confirmation of a root-knot nematode problem and allow mapping of current field infestation. The detection of any level of root galling usually suggests a root-knot nematode problem for subsequent planting of a susceptible crop, particularly within the immediate areas from which the galled plants were recovered.

\section{General Management Considerations}

Currently, nematode management considerations include crop rotation of less susceptible crops, cultural and tillage practices, use of nematode-free seed potatoes, and preplant nematicide treatments. Keep in mind that not all management practices are equally effective in controlling plant-parasitic nematodes; varying degrees of nematode control should be expected. Farm-specific conditions, such as soil type, temperature, and moisture, can help determine whether different practices can be effectively utilized for nematode management.

\section{Crop Rotation}

Many potato fields have been cropped annually to potato for many years due to limited options for economically viable cash crops that fit in a particular grower's operation. When possible, crop rotation with unrelated crops is a sound practice for reduction of nematode populations as well as other soilborne pests. Rotation with cash crops during the typical growing season or with cover crops not harvested for sale during typically fallow periods is beneficial. When a crop is planted that is not a host, or is a poor host, of the nematodes in a given field, nematode populations will steadily decline over time. In addition, certain crops produce allelochemicals which may actively reduce nematode populations. Brassicas (broccoli, cabbage, 
and cauliflower), sunn hemp, and velvet bean are potential rotation or summer cover crops known to produce allelochemicals with nematicidal effects. For some of these crops, further research is needed to determine the exact contribution of allelochemicals, as opposed to nonhost effects, to nematode management in field conditions. Even for crops that produce allelochemicals, it is important to consider the host status of the crop because growing a host crop will likely negate any benefit of allelochemicals for nematode management. Proper weed management is an important component of crop rotation for nematode management, as weeds can serve as hosts for plant-parasitic nematodes and increase or maintain populations during fallow or when a nonhost crop is grown. For example, nutsedge, pigweed, and lambsquarter, among many others, are generally good hosts of root-knot nematodes. The amount of time a field needs to be rotated to a nonhost crop to reduce nematode populations below a damaging level will vary based on nematode populations when rotation is initiated, soil type, and other management practices used. In general, one should expect reduction of nematode populations below a damaging level to take multiple seasons of a nonhost crop

It is not possible to find rotation or cover crops which will reduce populations of all nematode pests of potatoes, so it is important to determine which nematode species are present in a given field. When multiple species are present, it is often useful to design crop rotation to reduce root-knot nematodes, the most difficult nematodes to control with chemicals. Table 1 summarizes the reported host status of common rotation or summer cover crops in Florida potato production areas for the major potato nematodes. Note that nematode-crop interactions can vary by cultivar and nematode population, so the management success of a particular crop in a particular field may vary from what is reported in the literature. Grasses, such corn or sorghum-sudangrass, are excellent hosts of sting and stubby-root nematodes and should be avoided if possible when these nematodes are present. Certain summer cover crops, such as sunn hemp, velvet bean, and hairy indigo, may be useful for sting nematode management. Most cash crops commonly rotated with potato are hosts of the three major root-knot nematodes in Florida (southern, peanut, and Javanese root-knot nematodes) except for a few crops (soybean, tomato, sweet potato) for which resistant cultivars are available. Several summer cover crops (sunn hemp, sorghum-sudangrass, velvet bean, hairy indigo, and American jointvetch) are reported to be poor hosts of root-knot nematodes and may be useful for management of these nematodes. For more information, see these EDIS publications on Florida cover crop production (http://edis.ifas.ufl.edu/aa217), cover crops for root-knot nematode (http://edis.ifas.ufl.edu/in892), and nematode management using sunn hemp (http://edis. ifas.ufl.edu/ng043), cowpea (http://edis.ifas.ufl.edu/in516), and sorghum-sudangrass (http://edis.ifas.ufl.edu/in531). For further guidance on potential rotation or cover crops for nematode management, contact your local UF/IFAS Extension agent or Z. J. Grabau.

\section{Soil Management Practices}

Land should be disked as soon as possible after a crop is harvested to ensure death and desiccation or decomposition of all host plant tissues and weeds. Populations of nematodes, fungi, and other soilborne pests can continue to feed and reproduce on potatoes and weeds that remain alive after harvest, so prompt disking will help reduce total buildup of those pests. If other cultural considerations make it practical, a brief period of fallow during hot weather with at least two diskings to expose additional soil to desiccation and sunlight can reduce populations of nematodes. Prolonged periods of fallow are generally not recommended because of the potential for soil loss by erosion and loss of soil organic matter by oxidation.

\section{Varietal Resistance}

No commercially available potato varieties have resistance to any of the nematode pests encountered in Florida. While varieties with corky ringspot resistance are available, these cultivars are not cultivated commercially in Florida at the time of writing. Bacterial wilt caused by the bacterium Pseudomonas solanacearum can be more severe when rootknot nematodes are present (Weingartner and Shumaker 1990a). There are also commercial varieties with tolerance to bacterial wilt, but the varieties commonly grown in Florida are not known to have this tolerance.

\section{Chemical Control}

Most fields in which nematodes have previously damaged potatoes or other crops should be treated with chemical nematicides to improve potato production. This is especially true on land that is heavily cropped to potatoes and other crops susceptible to the same nematodes. Nematicides that may be used for potato production in Florida are listed in the following tables. Selection of a nematicide should be based on the kinds of nematodes and soilborne diseases present in the field, field conditions at soil preparation time, and intended market (degree of control needed). 


\section{Fumigant Nematicides}

Fumigants are pesticides that move through the soil as gases (Table 2). Some fumigants are broad-spectrum-they may have activity against nematodes, fungal or bacterial pathogens, and weeds. However, the current fumigants do not provide consistently excellent control of all of these pests (Table 3). Therefore, a combination of chemistries or management strategies is generally needed for pest management in potato production. Since fumigants must diffuse through soil as gases to be effective, the most effective fumigations occur when the soil is well drained, in seedbed condition, and at temperatures above $60^{\circ} \mathrm{F}$. The fine sands of the northeast Florida potato production area near Hastings and dry soils ( 12 to $15 \%$ available soil moisture content) are considered favorable for soil fumigation.

Soil conditions at fumigation are also mandated by Good Agricultural Practices (GAPs) established by the EPA in 2011. These GAPs are now listed on all fumigant labels and are intended to reduce pesticide emissions for pollution control and bystander safety. Residue from a previous crop must be worked into the soil to allow for decomposition prior to fumigation. This prevents plant residue from creating pathways for the fumigant to escape the soil. Most Florida potato growers rely on summer cover crops of sorghum-sudangrass that leave significant crop residues of large, undecomposed stalks, so growers should plan crop destruction and soil cultivation practices well in advance of fumigation to ensure decomposition of plant materials. In addition to increasing potential loss of fumigant to the atmosphere and decreasing efficacy, undecomposed residue provides shelter for nematodes, particularly root-knot nematodes. Therefore, proper residue management will maximize nematode control efficacy and minimize fumigant loss to the atmosphere. Another relevant GAP governs soil moisture, generally indicating that soil moisture in the top 9 inches of soil must be between 50 and $80 \%$ of soil capacity (field capacity) immediately prior to fumigant application, subject to the exception where soil moisture must exceed field capacity to form a bed. Fumigant application also requires buffer zones and written fumigant management plans.

\section{Non-Fumigant Nematicides}

Non-fumigant nematicides are liquid or granular products that move through the soil in water (Figure 8). All of the non-fumigants currently registered for use in potatoes are soil-applied, with the exception of Vydate C-LV and Return XL, which can also be applied to foliage (Table 4). Non-fumigant nematicides provide a narrow spectrum of activity, primarily targeting nematodes, or, in some cases, nematodes and fungal pathogens or insects. Because of this, non-fumigants require even more integrated use of other cultural or chemical pest control measures to manage other weeds and disease pests. Efficacy of non-fumigants varies by product, but non-fumigants are generally less effective than fumigants for control of most nematodes in vegetable crops. Newer chemistries, such as fluopyram (Velum Prime) and fluensulfone (Nimitz), pose less human safety risk and are less restrictive to use than older non-fumigant chemistries or fumigants, because they are less toxic and have fewer label restrictions. Older chemistries, such as oxamyl (Vydate C-LV and Return XL) and ethoprop (Mocap), are relatively toxic and require more personal protective equipment.

Non-fumigants work by coming into contact with nematodes in the soil, or, if the product has systemic activity, by being taken up by the plant (Table 5). Therefore, the ability of a product to dissolve and move in water (solubility) and the length of time it takes for the compound to break (persistence) greatly influence the efficacy of non-fumigants. Table 5 summarizes these properties for non-fumigants labeled for potato. Mobile non-fumigants (oxamyl, ethoprop, or fluensulfone) are likely to come in contact with nematodes in the soil more quickly than a poorly mobile non-fumigant. Mobile products also move out of the rooting zone more quickly, particularly with excess rainfall, reducing nematode exposure and increasing risk of leaching. A highly persistent nematicide will stay in the soil longer, increasing exposure to nematodes.

In addition to characteristics of a product, application methods and soil conditions will greatly influence nematicide efficacy. Always refer to the latest label instructions for proper application procedures. In general, non-fumigants are most effective when they are uniformly applied to soil and targeted toward the future rooting zone of the plant, where they will contact nematodes or be absorbed by the plant. Non-fumigant materials work best in moist soils, generally above $12 \%$ to $15 \%$ moisture. Proper tillage is also critical, particularly for relatively immobile products, in order to thoroughly mix non-fumigants in the soil where potatoes will be planted.

Mocap EC or Vydate C-LV is often used in fields in which stubby-root nematode and CRS occur. Soil fumigation does not effectively control stubby-root nematodes and CRS under Florida growing conditions (Weingartner and Shumaker 1990b), but these non-fumigants have significantly reduced CRS and other superficial tuber defects associated with damage by other nematodes. Recent studies in Florida have indicated that pairing a non-fumigant 
Mocap EC (applied on a broadcast basis preplant) or Vydate C-LV (applied as a sequence of in-furrow and foliar applications) with a preplant application of a registered fumigant nematicide (1,3-D or metam-sodium) is highly effective. At-plant or preplant non-fumigant applications are more effective than post-plant applications and that the returns of nematicide application diminish as time after crop emergence increases. In potato production, this applies primarily to foliar applications of oxamyl (Vydate C-LV or Return XL). Oxamyl applications after tuber initiation may not control CRS. Research in northeast Florida from 2016 to 2018 has shown that Nimitz is very effective for managing sting nematode, but further research is needed on its control of stubby-root nematodes and CRS (Grabau et al. 2019). Velum Prime has been useful for nematode control in potatoes in other states, but research is needed to determine efficacy in Florida and adapt application procedures to Florida production systems.

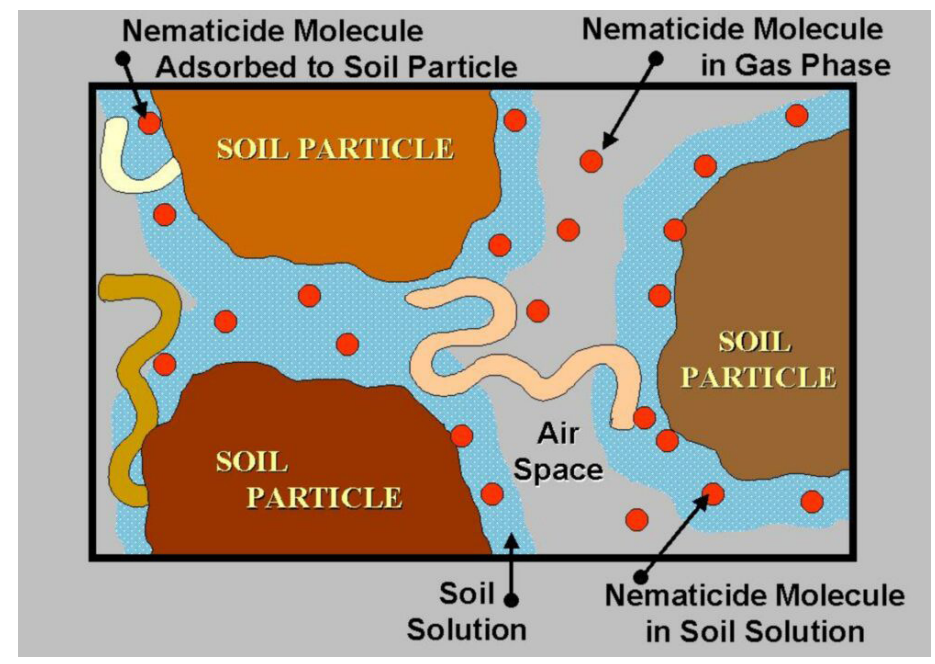

Figure 12. Nematodes encounter both liquid and gas phase nematicides in soil.

Credits: Joe Noling, UF/IFAS

\section{References}

Anwar, S. A., and M. V. McKenry. 2010. "Incidence and reproduction of Meloidogyne incognita on vegetable crop genotypes." Pakistan Journal of Zoology 42: 135-141.

Crow, W. T. 2018. Belonolaimus longicaudatus Rau (Nematoda: Secernentea: Tylenchida: Tylenchina: Belonolaimidae: Belonolaiminae). EENY618. Gainesville: University of Florida Institute of Food and Agricultural Sciences. http:// edis.ifas.ufl.edu/in395
Crow, W. T., D. P. Weingartner, D. W. Dickson, and R. McSorley. 2001. "Effect of sorghum-sudangrass and velvetbean cover crops on plant-parasitic nematodes associated with potato production in Florida." Journal of Nematology 33: $285-288$.

Crow, W., D. Weingartner, R. McSorley, and D. Dickson. 2000. "Damage function and economic threshold for Belonolaimus longicaudatus on potato." Journal of Nematology 32: 318-322.

Dover, K., K. H. Wang, and R. McSorley. 2018. Nematode Management Using Sorghum and Its Relatives. ENY716. Gainesville: University of Florida Institute of Food and Agricultural Sciences. http://edis.ifas.ufl.edu/in531

Gill, H. K., and R. McSorley. 2017. Cover Crops for Managing Root-Knot Nematodes. ENY063. Gainesville: University of Florida Institute of Food and Agricultural Sciences. http://edis.ifas.ufl.edu/in892

Khan, A. A., and M. W. Khan. 1991. "Penetration and development of Meloidogyne incognita race 1 and Meloidogyne javanica in susceptible and resistant vegetables." Nematropica 21 (1): 71-77.

Kinloch, R. A., and L. S. Dunavin. 1993. "Summer cropping effects on the abundance of Meloidogyne arenaria race 2 and subsequent soybean yield." Journal of Nematology 25: 806-808.

McSorley, R. 1994. "Changes in population densities of Meloidogyne spp and Paratrichodorus minor on winter rye cover crops." Nematropica 24: 151-160.

McSorley, R. 1999. "Host suitability of potential cover crops for root-knot nematodes." Journal of Nematology 31 : 619-623.

McSorley, R., and D. W. Dickson. 1995. "Effect of tropical rotation crops on Meloidogyne Incognita and other plantparasitic nematodes." Journal of Nematology 27: 535-543.

McSorley, R., D. W. Dickson, and J. A. DeBrito. 1994. “Host status of selected tropical rotation crops to 4 populations of root-knot nematodes." Nematropica 24: 45-53.

McSorley, R., and R. N. Gallaher. 1993. "Effect of crop rotation and tillage on nematode densities in tropical corn." Journal of Nematology 25: 814-819. 
Grabau, Z. J., P. A. Navia Gine, and J. W. Noling. 2019. Fluensulfone and 1,3-dichloroprene for plant-parasitic nematode management in potato production. Journal of Nematology. In-press.

Perez, E., D. Weingartner, E. Hiebert, and R. McSorley. 2000. "Tobacco rattle virus detection in potato tubers from northeast Florida by PCR and tissue blotting." American Journal of Potato Research 77: 363-368.

Rodriguez-Kabana, R., J. Pinochet, D. G. Robertson, and L. Wells. 1992. "Crop rotation studies with velvetbean (Mucuna deeringiana) for the management of Meloidogyne spp." Journal of Nematology 24: 662-668.

Rodriguez-Kabana, R., D. B. Weaver, D. G. Robertson, R. W. Young, and E. L. Carden. 1990. "Rotations of Soybean with 2 Tropical Legumes for the Management of Nematode Problems." Nematropica 20: 101-110.

Wang, K. H., R. J. McGovern, R. McSorley, and R. N. Gallaher. 2004. "Cowpea cover crop and solarization for managing root-knot and other plant-parasitic nematodes in herb and vegetable Crops." Soil and Crop Science Society of Florida Proceedings 63: 99-104.

Wang, K. H., and R. McSorley. 2018. Management of Nematodes and Soil Fertility with Sunn Hemp Cover Crop. ENY-717. Gainesville: University of Florida Institute of Food and Agricultural Sciences. http://edis.ifas.ufl.edu/ ng043

Wang, K. H., and R. McSorley. 2018. Management of Nematodes with Cowpea Cover Crops. ENY-712. Gainesville: University of Florida Institute of Food and Agricultural Sciences. http://edis.ifas.ufl.edu/in516

Weingartner, D., and J. Shumaker. 1990a. "Effects of soil fumigants and aldicarb on bacterial wilt and root-knot nematodes in potato." Journal of Nematology 22: 681-688.

Weingartner, D., and J. Shumaker. 1990b. "Effects of soil fumigants and aldicarb on corky ringspot disease and Trichodorid nematodes in potato." Journal of Nematology 22: 665-671.

Weingartner, D. P., R. McSorley, and R. W. Goth. 1993. "Management strategies in potato for nematodes and soil-borne diseases in subtropical Florida." Nematropica 23 (2): 233-245.

Wright, D. L., C. Mackowiak, and A. Blount. 2017. Cover Crops. SS-AGR-66. Gainesville: University of Florida Institute of Food and Agricultural Sciences. http://edis.ifas. ufl.edu/aa217 
Table 1. Host status of selected cash and summer cover crops for common plant-parasitic nematodes in potato-growing regions of Florida.

\begin{tabular}{|c|c|c|c|c|c|}
\hline & $\begin{array}{l}\text { Southern } \\
\text { Root-Knot } \\
\text { Nematode }\end{array}$ & $\begin{array}{c}\text { Peanut } \\
\text { Root-Knot } \\
\text { Nematode }\end{array}$ & $\begin{array}{l}\text { Javanese } \\
\text { Root-Knot } \\
\text { Nematode }\end{array}$ & $\begin{array}{l}\text { Stubby-Root } \\
\text { Nematode }\end{array}$ & Sting Nematode \\
\hline \multicolumn{6}{|l|}{ Cash Crops } \\
\hline Broccoli & Varies & Host & Host & Unknown & Unknown \\
\hline Cabbage & Varies & Host & Varies & Host & Host \\
\hline Cauliflower & Varies & Host & Varies & Unknown & Host \\
\hline Corn & Host & Varies & Host & Host & Host \\
\hline Soybean & Varies $^{2}$ & Host & Host & Host & Host \\
\hline Sweet potato & Varies $^{2}$ & Host & Host & Unknown & Unknown \\
\hline Tomato & Varies $^{2}$ & Varies $^{2}$ & Varies $^{2}$ & Host & Host \\
\hline Watermelon & Host & Host & Host & Unknown & Poor/nonhost \\
\hline \multicolumn{6}{|l|}{ Cover Crops } \\
\hline Sorghum-sudangrass & Poor/nonhost & Poor/nonhost & Poor/nonhost & Host & Host \\
\hline Sunn hemp & Poor/nonhost & Poor/nonhost & Poor/nonhost & Unknown & Poor/nonhost \\
\hline Cowpea & Varies $^{2}$ & Varies $^{2}$ & Varies $^{2}$ & Varies & Host \\
\hline Velvet bean & Poor/nonhost & Poor/nonhost & Poor/nonhost & Host & Poor/nonhost \\
\hline Hairy indigo & Poor/nonhost & Poor/nonhost & Poor/nonhost & Unknown & Poor/nonhost \\
\hline Jointvetch & Poor/nonhost & Poor/nonhost & Poor/nonhost & Host & Unknown \\
\hline \multicolumn{6}{|c|}{$\begin{array}{l}\text { 'Information is based on observations and literature (Anwar and McKenry 2010; Crow et al. 2001; Khan and Khan 1991; Kinloch and Dunavin } \\
\text { 1993; McSorley and Gallaher 1993; McSorley, Dickson, DeBrito 1994; McSorley 1994; McSorley and Dickson 1995; Perez, Weingartner, McSorley } \\
\text { 2000; Rodriguez-Kabana et al. 1990; Rodriguez-Kabana et al. 1992; Wang et al. 2004; Weingartner, McSorley, Goth 1993) } \\
\text { at the time of publication. Relationships may differ for specific nematode populations and crop cultivars. Poor = poor or nonhost; Good = } \\
\text { good host; Unknown = host status is unknown or has not been formally reported; Varies = susceptibility varies by cultivar (may suggest an } \\
\text { intermediate level of susceptibility). } \\
{ }^{2} \text { Resistant cultivars are available. Most cultivars are good hosts. } \\
{ }^{3} \text { Host range of southern and peanut root-knot nematodes and sting nematode varies by population. }\end{array}$} \\
\hline
\end{tabular}


Table 2. Fumigant nematicides for potatoes in Florida.

\begin{tabular}{|c|c|c|c|}
\hline \multirow[b]{2}{*}{ Nematicide $^{2}$} & \multicolumn{2}{|c|}{ Broadcast Application Rates ${ }^{1}$} & \multirow[b]{2}{*}{ In-the-Row Applications } \\
\hline & Amount per acre & $\begin{array}{l}\text { fl oz/1000 ft/ chisel spaced } 12 \\
\text { in apart }\end{array}$ & \\
\hline Telone $\|^{3}$ & 9 to $12 \mathrm{gal}$ & 26 to 35 & $\begin{array}{l}\text { May be concentrated in row. Do not exceed broadcast } \\
\text { rate. }\end{array}$ \\
\hline Telone $\mathrm{C}-17^{3}$ & 10.8 to $17.1 \mathrm{gal}$ & 31.8 to 50.2 & $\begin{array}{l}\text { May be concentrated in row. Do not exceed broadcast } \\
\text { rate. }\end{array}$ \\
\hline Telone C-35 & 13 to $20.5 \mathrm{gal}$ & 38.2 to 60.2 & $\begin{array}{l}\text { May be concentrated in row. Do not exceed broadcast } \\
\text { rate. }\end{array}$ \\
\hline Pic-Clor 60 & 19 to $31.5 \mathrm{gal}$ & 57 to 90 & $\begin{array}{l}\text { May be concentrated in row. Do not exceed broadcast } \\
\text { rate. }\end{array}$ \\
\hline Chloropicrin 99\% & 150 to $350 \mathrm{lb}$ & - & $\begin{array}{l}\text { May be concentrated in row. Do not exceed broadcast } \\
\text { rate. }\end{array}$ \\
\hline Vapam HL & $75 \mathrm{gal}$ & - & $\begin{array}{l}\text { Must proportionally reduce rates and modify flow for } \\
\text { drip or in-row chisel application. See label. }\end{array}$ \\
\hline KPam HL & $60 \mathrm{gal}$ & - & $\begin{array}{l}\text { Must proportionally reduce rates and modify flow for } \\
\text { drip or in-row chisel application. See label. }\end{array}$ \\
\hline Dominus & $40 \mathrm{gal}$ & - & $\begin{array}{l}\text { Must proportionally reduce rates and modify flow for } \\
\text { drip or in-row chisel application. See label. }\end{array}$ \\
\hline \multicolumn{4}{|c|}{$\begin{array}{l}{ }^{1} \text { Rates provided only for mineral soils. Higher rates may be allowed for heavier textured (loam, silt, clay) or highly organic soils. At the time of } \\
\text { publication, rates are believed to be correct for products named and similar products of other brand names. However, the grower has the final } \\
\text { responsibility to see that each product is used legally. Read the label of the product to be sure that you are using it properly. } \\
{ }^{2} \text { All of the fumigants mentioned are for retail sale and use only by state-certified applicators or persons under their direct supervision. New } \\
\text { supplemental labeling for the Telone products must be in the hands of the user at the time of application. } \\
{ }^{3} \text { Higher application rates are allowed in the presence of cyst-forming nematodes. }\end{array}$} \\
\hline
\end{tabular}

Table 3. Generalized summary of maximum use rate and relative effectiveness of various soil fumigant alternatives to methyl bromide for nematode, soilborne disease, and weed control in Florida.

\begin{tabular}{|c|c|c|c|c|}
\hline \multirow[b]{2}{*}{$\begin{array}{l}\text { Fumigant Trade } \\
\text { Name }^{1}\end{array}$} & \multirow[b]{2}{*}{ Active Ingredient } & \multicolumn{3}{|c|}{ Relative Pesticidal Activity } \\
\hline & & Nematode & Disease & Weed \\
\hline Chloropicrin & Chloropicrin & None to poor & Excellent & Poor \\
\hline Vapam HL & Metam-sodium & Good to poor & Good to poor & Good to poor \\
\hline Telone II & 1,3-Dichloropropene & Good to excellent & None to poor & Poor \\
\hline Telone C17 & 1,3-Dichloropropene + chloropicrin & Good to excellent & Good & Poor \\
\hline Telone C35 & 1,3-Dichloropropene + chloropicrin & Good to excellent & Good to excellent & Poor to fair \\
\hline Pic-Clor 60 & 1,3-Dichloropropene + chloropicrin & Good to excellent & Good to excellent & Poor to fair \\
\hline KPam HL & Metam potassium & Good to poor & Good to poor & Good to poor \\
\hline Dominus & Allyl isothiocyanate & Good to poor & Good to poor & Good to poor \\
\hline
\end{tabular}


Table 4. Non-fumigant nematicides for potatoes in Florida.

\begin{tabular}{|c|c|c|c|}
\hline $\begin{array}{l}\text { Nematicide } \\
\text { (Active Ingredient) }^{1}\end{array}$ & Labeled Rate $^{2}$ & Application Timing & Application Methods \\
\hline $\begin{array}{l}\text { Mocap } 15 G^{3} \\
\text { (ethoprop) }\end{array}$ & $\begin{array}{l}40-60 \mathrm{lb} / \mathrm{acre} \text { if } \\
\text { broadcast; } \\
1.4 \mathrm{lb} / 1000 \text { row-foot if } \\
\text { banded }\end{array}$ & $\begin{array}{l}\text { 1. Broadcast }<2 \text { weeks } \\
\text { preplant crop emergence } \\
\text { or } \\
\text { 2. Banded at-plant }\end{array}$ & $\begin{array}{l}\text { 1. Broadcast spread granules and till to } 2-4 \\
\text { inches deep. } \\
2 \text {. In } 12 \text {-inch band before planter foot or over } \\
\text { closed furrow. Till to } 2-4 \text { inches. Avoid contact } \\
\text { with seed pieces. }\end{array}$ \\
\hline $\begin{array}{l}\text { Mocap EC } \\
\text { (ethoprop) }\end{array}$ & $\begin{array}{l}1-1.5 \mathrm{gal} / \text { acre if } \\
\text { broadcast; } \\
4.4 \mathrm{oz} / 1000 \text { row-foot if } \\
\text { banded }\end{array}$ & $\begin{array}{l}\text { 1. Broadcast }<2 \text { weeks } \\
\text { preplant to crop emergence } \\
\text { or } \\
\text { 2. Banded at-plant }\end{array}$ & $\begin{array}{l}\text { 1. Broadcast spray and till to } 2-4 \text { inches deep. } \\
\text { 2. In } 12 \text {-inch band before planter foot or over } \\
\text { closed furrow. Till to } 2-4 \text { inches. Avoid contact } \\
\text { with seed pieces. }\end{array}$ \\
\hline $\begin{array}{l}\text { Vydate C-LV or Return XL } \\
\text { (Oxamyl) }\end{array}$ & $\begin{array}{l}238 \text { oz/acre per year } \\
\text { total. }{ }^{4} \\
34-68 \text { oz/acre at } \\
\text { planting. } \\
34 \text { oz/acre per foliar } \\
\text { application. } \\
4 \text { foliar and } 5 \text { total } \\
\text { applications per year } \\
\text { maximum }\end{array}$ & & \\
\hline Nimitz (fluensulfone) & $\begin{array}{l}3.5-7 \mathrm{pt} / \mathrm{acre} \text { (banded } \\
\text { applications not to be } \\
\text { concentrated in row) }\end{array}$ & At or before planting & \\
\hline Velum Prime (fluopyram) & $\begin{array}{l}6.5 \mathrm{oz} / \text { acre per } \\
\text { application. } \\
13.7 \text { oz/acre per year. }{ }^{5}\end{array}$ & $\begin{array}{l}\text { Up to } 7 \text { days before harvest. At } \\
\text { or pre-plant recommended }\end{array}$ & Through overhead irrigation system. \\
\hline \multicolumn{4}{|c|}{$\begin{array}{l}{ }^{1} \text { Provided as guidelines only. Information is subject to changing product registration and labeling. Always read and follow label instructions. } \\
\text { The mention of a product or trade name does not imply endorsement to the exclusion of other products. All of the nematicides mentioned are } \\
\text { restricted use pesticides for use only by state-certified applicators or persons under their direct supervision. } \\
{ }^{2} \text { Do not exceed greatest listed label rate. Only } 1 \text { application per growing season is allowed unless noted otherwise. } \\
{ }^{3} \text { Do not apply Mocap where sorghum will be grown during the same year, as its residual activity may cause serious injury to sorghum. } \\
{ }^{4} \text { Maximum application rate varies by target nematode and population. See label for details. } \\
{ }^{5} \text { Velum Prime is considered a FRAC group } 7 \text { fungicide. Rotate chemistries. }\end{array}$} \\
\hline
\end{tabular}

Table 5. Characteristics of non-fumigant nematicides labeled for use in Florida potatoes.

\begin{tabular}{|c|c|c|c|c|c|}
\hline Active Ingredient & Trade Name(s) & $\begin{array}{l}\text { Handler Toxicity } \\
\text { Category' }\end{array}$ & $\begin{array}{l}\text { Soil Movement } \\
\text { (Water Solubility) }\end{array}$ & $\begin{array}{l}\text { Persistence in Soil } \\
\text { (Half-Life) }\end{array}$ & Systemic in Plant? \\
\hline Ethoprop & $\begin{array}{l}\text { Mocap 15G, Mocap } \\
\text { EC }\end{array}$ & Danger & $\begin{array}{l}\text { High } \\
\text { (843 ppm) }\end{array}$ & $\begin{array}{l}\text { Short } \\
\text { (3-56 days) }\end{array}$ & No \\
\hline Oxamyl & $\begin{array}{l}\text { Vydate C-LV, Return } \\
\text { XL }\end{array}$ & Danger & $\begin{array}{l}\text { High } \\
(240,000 \text { ppm })\end{array}$ & $\begin{array}{l}\text { Short } \\
\text { (7 days) }\end{array}$ & Yes \\
\hline Fluensulfone & Nimitz & Caution & $\begin{array}{l}\text { Medium } \\
\text { (545 ppm) }\end{array}$ & $\begin{array}{l}\text { Short } \\
\text { (7-17 days) }\end{array}$ & No \\
\hline Fluopyram & Velum Prime & Warning & $\begin{array}{l}\text { Low } \\
\text { (10 ppm) }\end{array}$ & $\begin{array}{l}\text { Long } \\
\text { (162-746 days) }\end{array}$ & $\begin{array}{l}\text { Yes, limited } \\
\text { movement }\end{array}$ \\
\hline
\end{tabular}

